\title{
EFFECT OF SULPHUR AND PHOSPHATE FERTILIZATION ON GROWTH YIELD AND FRUIT QUALITY OF PEPPER (Capsicum annuum, L.) b-Effect on yield, fruit quality and nutrient components Sarg, Sawsan, M.H. *; M.A. Hassan*; S. K. El-Seifi ${ }^{* * *}$ and M.K. Rakha** \\ *Hort. Dept., Fac. Agric., Suez Canal Univ. \\ ${ }^{\star *}$ Hort. Res.Inst., Agric. Res. Center
}

\section{ABSTRACT}

Two field experiments were carried out at El-Baramoon Farm, Mansoura Horticultural Research Station, during the summer seasons of 2002 and 2003. The study aimed to investigate the effect of sulphur levels $(0,150$ and $300 \mathrm{~kg} \mathrm{~S} / \mathrm{fed}$.) and phosphorus fertilization levels $\left(0,30,60\right.$ and $\left.90 \mathrm{~kg} \mathrm{P}_{2} \mathrm{O}_{5} / \mathrm{fed}_{\text {. }}\right)$ and their interaction on yield components (number of fruits/plant, average fruit weight, fruit yield/plant, early and total yield/ fed.), fruit physical characteristics (fruit length, fruit diameter, fruit shape index, flesh thickness and dry matter \%), fruit chemical compositions (TSS, carotenoids, Vit. C, total acidity) and fruit mineral contents i.e. N, P, K, S, Fe, Zn. and Mn of sweet pepper cv. California Wonder. The obtained results showed that all the previous parameters were increased with the increase of sulphur levels from zero up to $300 \mathrm{~kg} / \mathrm{fed}$ compared with control. The increments were significant except those of number of fruits/ plant in the two seasons, fruit shape index in the second season, flesh thickness in both seasons which showed no significant differences. All tested fruit parameters were significantly increased with the addition of phosphorus compared with control However, the differences among treatments were not significant in each of No. fruits/plant, fruit shape index and flesh thickness in both seasons. Results also declared that the highest contents of $\mathrm{Fe}, \mathrm{Zn}$ and $\mathrm{Mn}$ were noticed with $60 \mathrm{~kg} \mathrm{P} \mathrm{O}_{5} /$ fed then decreased with $90 \mathrm{~kg} \mathrm{P}_{2} \mathrm{O}_{5} /$ fed and the differences in $\mathrm{Mn}$ contents were insignificant. The interaction effects showed that the highest level of sulphur (300 kg S/fed) plus the highest phosphorus level (90 kg $\mathrm{P}_{2} \mathrm{O}_{5} / f e d$.) had superior effects on all the studied parameters, except that $\mathrm{Fe}, \mathrm{Zn}$ and $\mathrm{Mn}$ contents which gave their highest contents with $300 \mathrm{~kg} \mathrm{~S} /$ fed plus $60 \mathrm{~kg} \mathrm{P}_{2} \mathrm{O}_{5} /$ fed.

\section{INTRODUCTION}

Sweet pepper (Capsicum annuum L.) is an important vegetable and popular crop grown in tropical and subtropical regions of the world for the purpose of exportation and local markets usage. In Egypt, sweet pepper occupied 22853 faddans in 2005, with an average of 20.05 ton/fed. ${ }^{*}$ Sweet pepper fruits are known to be very rich in vitamins, especially vitamins " $A$ " and "C". It is also a good source of B-carotene. Green fruits contain chlorophyll $\mathrm{A}$ and chlorophyll $\mathrm{B}$, which are probably synthesized denovo during chloroplast development (Rajput and Poruleker,1998).

* Cited from the Economic and Statistical Departement, Ministry of Agriculture, Egypt, 2005 
Sarg, Sawsan, M.H. et al.

Increasing sweet pepper production and improving fruit quality are important to increase the exported yield. Several factors affect plant growth, yield and fruit quality of pepper, among them the nutritional supplies with sulphur and phosphorus fertilization, since several investigations indicated a good relationship between sulphur and solubility of phosphorus under alkaline soils (Rivera and Irgazarry, 1984).Sulphur is a constituent of amino acids methionine and cystine. The vitamins biotin and thiamine contain sulphur, and the structure of proteins is determined to a considerable extent by sulphur groups. As with other essential elements $S$ plays a unique role in plant metabolism. Sulphur was reported to improve yield and quality of sweet pepper (Shaheen and Omar, 1989). Sulphur is important to increase the yield components and quality of other vegetables (Youssef, 2002 on pea ; Radwan and tawfik , 2004 on potato and Smatanova et al., 2004 on spinach and pepper).

Topcuoglu and Yalcin (1997) reported that $S$ application increased total $\mathrm{S}, \mathrm{N}, \mathrm{P}, \mathrm{K}, \mathrm{Ca}, \mathrm{Mg}, \mathrm{Zn}, \mathrm{Mn}, \mathrm{Cu}$ and active $\mathrm{Fe}$ contents in tomato leaf petiole and fruit tissues. El-Fayoumy and El-Gamal (1998) indicated that $S$ application increased the availability and uptake of $\mathrm{P}, \mathrm{Fe}, \mathrm{Mn}, \mathrm{Zn}, \mathrm{Cu}$ and also increased vitamin $\mathrm{C}$, carotene, starch and protein in potato tubers.

Phosphorus is a constituent of nucleic acid and nuclei; P plays a good role in plant metabolism, structure, and reproduction that can not be replaced by any other element. The phosphate esters in plant growth has particular role in the conversion of carbohydrates and in the metabolism of starch. Furthermore, phosphorus is important for the ripening of seeds and fruits. Davies et al., (1999), Murgan et al.(2002) and Jaggi et al., (2003) concluded that phosphorus application increased pepper yield and improved fruit quality.

Concerning the combined effect of $S$ and $P$ Olsen et al., (1993) reported that $P$ and $S$ fertilizers was of great importance to maximize fresh wt. of bell pepper marketable fruits. Also, Jaggi et al., (2003) and sarker et al.,(2003) confirmed the positive effect of both $\mathrm{S}$ and $\mathrm{P}$ application on the yield and fruit quality of pepper therefore, this study aimed to improve yield and quality of pepper fruits through $\mathrm{S}$ and $\mathrm{P}$ application.

\section{MATERIALS AND METHODS}

Two field experiments were carried out at El-Baramoon Farm of Mansoura Horticultural Research Station, during summer seasons of 2002 and 2003 to study the effect of different levels of sulphur, phosphorus and their interaction on fruit yield and its components as well as chemical compositions of fruits. On March $20^{\text {th }}$, of both 2002 and 2003 seasons, sweet pepper seeds cv. California Wonder were sown in the nursery in $2 \times 2 \mathrm{~m}$. beds. After six weeks, seedlings were transplanted to the field, $30 \mathrm{~cm}$ a part on one side of the ridge. The experimental unit was consisted of 4 rows, each of $4 \mathrm{~m}$ long and $0.7 \mathrm{~m}$ width with an area of $11.2 \mathrm{~m}^{2}$.

\section{Experimental design and treatments:}

A complete randomized blocks design in split plot system, with 3 replications was adopted. Main plots were occupied with sulphur levels $(0$, 
150 and $300 \mathrm{~kg} / \mathrm{fed}$.$) , whereas phosphorus levels (0,30,60$ and $90 \mathrm{~kg}$ $\mathrm{P}_{2} \mathrm{O}_{5} / \mathrm{fed}$.) were placed in the subplots. The experiment includes 12 treatments, which were the combination of 3 sulphur $x 4$ phosphorus levels. Sulphur was applied once before transplanting and during soil preparation, whereas phosphorus was applied as Ca-superphosphate $\left(15.5 \% \mathrm{P}_{2} \mathrm{O}_{5}\right)$ in two equal doses, before transplanting and 30 days later.

All plots were fertilized equally with $\mathrm{N}$ at $200 \mathrm{~kg} \mathrm{~N} / \mathrm{fed}$. using ammonium sulphate $(20.5 \% \mathrm{~N})$ and $50 \mathrm{~kg} \mathrm{~K} \mathrm{~K}_{2} \mathrm{O} / \mathrm{fed}$. as potassium sulphate $\left(48 \% \mathrm{~K}_{2} \mathrm{O}\right)$. Also, all plants received similar cultural practices as commonly recommended.

\section{Recorded data:}

The following measurements and determinations were carried out in both seasons:

\section{Fruit yield and its components:}

All harvested fruits from the each plot, were used to calculate the following parameters:

Number of fruit per plant, average fruit weight (gm), fruit yield (gm) per plant, early yield (ton) per faddan: It was considered as the summation of the first four harvests according to El-Gandour, (1965).

Total fruit yield (ton)per faddan: calculated based on fruit yield/plot.

Fruit physical characteristics: including fruit length, L, $(\mathrm{cm})$, fruit diameter ,D, $(\mathrm{cm})$, fruit shape index $(\mathrm{L} / \mathrm{D})$ and flesh thickness $(\mathrm{cm})$ were determined.

Dry matter content: Fresh samples were allowed to dry in oven at $70^{\circ} \mathrm{C}$ for $48 \mathrm{~h}$. until constant weight, and percent of dry matter was calculated.

Fruit chemical properties:

A representative samples of 20 fruits were taken from each plot to determine the following properties.

Total soluble solids percentage (TSS\%): determined by a hand refractometer.

Total carotenoids: Total carotenoid contents of fruits were determined and calculated according to the method of Kirck and Allan (1965).

Vitamin C and acidity: determined by titration against 2,4,6dichlorophenol indophenol and phenolphytheline, respectively, according to methods of A.O.A.C (1970).

All collected data were subjected to statistical analysis of variance for split-plot design, and means were separated using Least significant difference test as mentioned by Snedecor and Cochran (1980).

Table (1) show mechanical and chemical analysis of the experimental soil which conducted at Mansoura Center of Soil Improvement, according to methods of Black (1965) and Page(1982. 
Sarg, Sawsan, M.H. et al.

Table (1): Physical and chemical analysis of the experimental soil, during 2002 and 2003 seasons.

\begin{tabular}{|c|c|c|}
\hline \multirow[t]{2}{*}{ Soil properties } & \multicolumn{2}{|c|}{ Season } \\
\hline & 2002 & 2003 \\
\hline \multicolumn{3}{|l|}{ A- Physical analysis } \\
\hline Coarse sand\% & 1.92 & 2.12 \\
\hline Fine sand $\%$ & 22.57 & 22.79 \\
\hline Silt \% & 26.11 & 25.96 \\
\hline Clay \% & 49.40 & 49.13 \\
\hline Soil type & Clay & Clay \\
\hline \multicolumn{3}{|l|}{ B- Chemical analysis } \\
\hline Total nitrogen \% & 0.12 & 0.15 \\
\hline Available phosphorus (ppm) & 7.15 & 7.95 \\
\hline Exchangeable potassium (ppm) & 215 & 229 \\
\hline $\mathrm{CaCO}_{3} \%$ & 2.80 & 2.75 \\
\hline Organic matter \% & 1.90 & 2.10 \\
\hline $\mathrm{EC}\left(\mathrm{mmhos} / \mathrm{cm}, 25^{\circ} \mathrm{C}\right)$ & 1.25 & 1.29 \\
\hline $\mathrm{pH}(1: 2: 5 \mathrm{w} / \mathrm{v})$ & 8.02 & 7.90 \\
\hline \multicolumn{3}{|l|}{ C- Soluble anions (meq/L) } \\
\hline $\mathrm{Cl}^{-}$ & 3.49 & 3.43 \\
\hline $\mathrm{HCO}_{3}$ & 3.15 & 3.18 \\
\hline $\mathrm{CO}_{3}^{-}$ & 0.00 & 0.00 \\
\hline $\mathrm{SO}_{4}^{-}$ & 5.11 & 5.18 \\
\hline \multicolumn{3}{|l|}{ D- Soluble cations (meq/L) $\mathrm{Ca}^{++}$} \\
\hline $\mathrm{Ca}^{++}$ & 4.00 & 3.97 \\
\hline $\mathrm{Mg}^{++}$ & 1.29 & 1.27 \\
\hline $\mathrm{Na}$ & 1.19 & 1.22 \\
\hline $\mathrm{K}$ & 5.27 & 5.33 \\
\hline \multicolumn{3}{|l|}{ F- Available micronutrients (ppm) } \\
\hline $\mathrm{Fe}$ & 3.59 & 3.63 \\
\hline $\mathrm{Zn}$ & 1.31 & 1.29 \\
\hline $\mathrm{Cu}$ & 0.53 & 0.55 \\
\hline $\mathrm{Mn}$ & 1.48 & 1.43 \\
\hline
\end{tabular}

RESULTS AND DISCUSSION

Effect of sulphur and phosphorus levels on fruit yield.

Effect of sulphur:

Data presented in Table (2) show that number of fruits/plant increased with increasing sulphur levels although the differences did not reach the level of significance in both seasons of study. Results in the same table reveal significant increase in both average fruit weight and yield of fruits/plant with each increase in sulphur level. The increase in yield /plant over the control were $15.07 \%, 31.31 \%$ and $10.28 \%, 26.79 \%$ with 150 and $300 \mathrm{~kg} \mathrm{~S} / \mathrm{fed}$ in the first and second seasons, respectively. It could be concluded that application of sulphur had a stimulative effect on the growth and yield of sweet pepper. This might explained the importance of $S$ in improving yield and quality by influencing the $S$ containing amino acids, which are the building blocks of proteins, and along with starch are responsible forformation of fruits (Arora and Luchra, 1970 and Gopal et al., 2003,). Results in Table (2) 
also indicated that both early and total yield/ fed. were significantly increased with the increase in sulphur level compared with controls. The increments were associated with the increase in the sulphur levels in both seasons. The favorable effects of sulphur may be due to the fact that it is essential element for metabolism especially protein synthesis (Freney et al., 1978 and Russell, 1988). Furthermore, $S$ is considered as a fungicide and it affects soil nematodes, soil born diseases and some other plant pests (Hilal et al., 1990 a). Each of $S$ and $P$ elements has a distinct effect on improving the yield and its components (Mazrouh, 2000) on tomato. These results are in harmony with those of Shaheen and Omar (1989), Shaheen et al. (1989 b) on sweet pepper, Hewedy (1999), Gopal et al. (2003) both on tomato and Smatanova et al. (2004) on spinach and pepper.

\section{Effect of phosphorus:}

Data in Table (2) indicate that number of fruit/plant increased with the increase in phosphorus levels, although these increments were not significant in both seasons. It is clear from such data that average fruit weigh and yield of fruits/plant were significantly increased with each increase in phosphorus levels. This was obviously occurred in the two seasons. The increments in the yield were $22.35 \% ; 29 \%, 49.76 \% ; 25.68 \%, 31.83 \%$ and $48.98 \%$ for the 30,60 and $90 \mathrm{~kg} \mathrm{P}_{2} \mathrm{O}_{5} / \mathrm{fed}$. in the first and in the second seasons, respectively. This may be due to the role of phosphorus as an essential component of many organic compounds in plant, which indirectly may reflect positively on yield (Marschner, 1995).

Results of Table (2) also show that early yield and total yield/ fed. were significantly increased with the increase in the added $\mathrm{P}$ levels.

Table (2). Effect of each of sulphur and phosphorus on yield and its components of sweet pepper plants during 2002 (S1) and 2003 (S2) seasons.

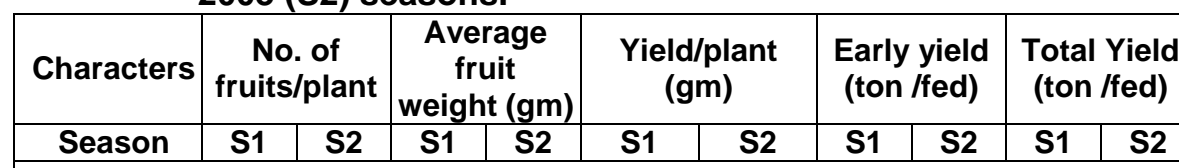

\section{Treatments}

\begin{tabular}{|c|c|c|c|c|c|c|c|c|c|c|}
\hline \multicolumn{11}{|l|}{ kg S/fed } \\
\hline Control & 11.86 & 11.81 & 4.04 & 56.44 & 640.91 & 666.56 & 7.46 & \begin{tabular}{|l|}
7.98 \\
\end{tabular} & 11.55 & 11.97 \\
\hline 150 & 12.67 & 12.74 & 58.21 & 57.70 & \begin{tabular}{|l|}
737.52 \\
\end{tabular} & \begin{tabular}{|l|}
735.10 \\
\end{tabular} & 8.41 & \begin{tabular}{|l|}
8.72 \\
\end{tabular} & 13.01 & 13.32 \\
\hline 300 & 14.01 & 13.76 & 60.07 & 61.42 & 841.58 & 845.14 & 9.96 & 10.01 & 15.07 & 15.25 \\
\hline L.S.D & N.S & N.S & 1.04 & 0.88 & & & 0.13 & 0.31 & 0.54 & 0.47 \\
\hline \multicolumn{11}{|l|}{$\mathrm{kg} \mathrm{P}_{2} \mathrm{O}_{5} / \mathrm{fed}$} \\
\hline Control & 10.93 & 111.0 & 54.12 & 53.50 & 591.53 & 592.25 & 6.91 & 7.28 & 10.45 & 10.8 \\
\hline 30 & 12.76 & 12.55 & 56.72 & 59.31 & 723.75 & 744.34 & 8.24 & \begin{tabular}{|l|}
8.56 \\
\end{tabular} & 12.90 & 13.31 \\
\hline 60 & 13.22 & 13.07 & 57.72 & 59.92 & 763.06 & 780.76 & 8.92 & \begin{tabular}{|l|}
9.22 \\
\end{tabular} & 13.75 & 14.07 \\
\hline 90 & 14.47 & 14.38 & 61.22 & 61.36 & 885.85 & \begin{tabular}{|l|}
882.36 \\
\end{tabular} & 10.39 & 10.56 & 15.74 & 15.81 \\
\hline L.S.D. at $5 \%$ & N.S & N.S & 1.14 & 1.08 & 12.08 & 9.20 & 0.12 & \begin{tabular}{|l|}
0.26 \\
\end{tabular} & 0.45 & \begin{tabular}{|l|}
0.53 \\
\end{tabular} \\
\hline
\end{tabular}

The highest total yield gained from plants fertilized with $\mathrm{P}$ at $90 \mathrm{~kg}$ $\mathrm{P}_{2} \mathrm{O}_{5} / \mathrm{fed}$. The increment in pepper fruit yield as a result of phosphorus application may be due to its role in vital growth processes, which are 
essential in all living cells and plays an important role in plant metabolism. It is also important for root development, the ripening of seeds and fruits as well as for the efficient functioning and utilization of nitrogen (Russell, 1988 and Mazrouh, 2000). These results are in accordance with those of Nigri et al. (1999), Murugan et al. (2002), Yusdar and Hanafi (2002), Kaya et al. (2003) and Muthumanickam (2003). Who concluded that yield and quality of pepper plants improved with increasing P levels.

The effect of sulphur and phosphorus interaction:

Data in Table (3) show that the interaction effects of $S$ and $P$ on number of fruits /plant were not significant within the various, levels throughout the two seasons. In contrary, these interaction effects on average weight of fruit and yield per plant in the two seasons were significant. The highest values were observed in plants treated with sulphur at $300 \mathrm{~kg} \mathrm{~S} /$ fed and phosphorus at $90 \mathrm{~kg} \mathrm{P}_{2} \mathrm{O}_{5} / \mathrm{fed}$. The lowest yield values were gained from the control plants in the two seasons of study, the other treatments showed intermediate values. Mazrouh (2000) and Gopal et al. (2003) confirmed that application of $\mathrm{P}$ and $\mathrm{S}$ together increased average fruit weight and yield of tomato.

Data in Table (3) also declared that the highest early yield/ fed., was gained from plants received the highest level of both sulphur $(300 \mathrm{~kg} / \mathrm{fed})$ and phosphorus (90 kg/fed) i.e. 12.71 and 12.27 tons /fed., in the first and second seasons, respectively. The lowest early yield was harvested from the control plants, i.e. 5.88 and 6.58 tons per fed., in the first and second seasons, respectively.

Table (3). Effect of interaction of sulphur and phosphorus on yield and its components of sweet pepper plants, during2002 (S1) and 2003 (S2) seasons.

\begin{tabular}{|c|c|c|c|c|c|c|c|c|c|c|c|}
\hline \multirow{2}{*}{\multicolumn{2}{|c|}{ Characters }} & \multicolumn{2}{|c|}{$\begin{array}{c}\text { No of } \\
\text { fruits/plant }\end{array}$} & \multicolumn{2}{|c|}{$\begin{array}{l}\text { Average } \\
\text { wt. of fruit } \\
\text { (gm) }\end{array}$} & \multicolumn{2}{|c|}{$\begin{array}{l}\text { Yield/plant } \\
\text { (gm) }\end{array}$} & \multicolumn{2}{|c|}{$\begin{array}{l}\text { Early } \\
\text { yield/fed } \\
\text { (ton) }\end{array}$} & \multicolumn{2}{|c|}{$\begin{array}{c}\text { Total } \\
\text { yield/fed } \\
\text { (ton) }\end{array}$} \\
\hline & & S1 & S2 & s1 & S2 & S1 & S2 & S1 & S2 & S1 & S2 \\
\hline \multicolumn{12}{|c|}{ Treatments } \\
\hline \multicolumn{12}{|c|}{ 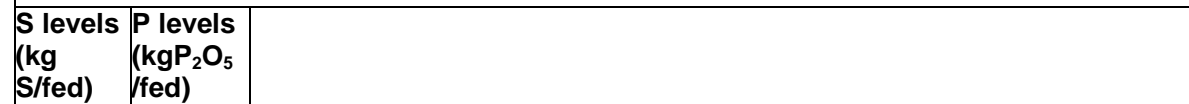 } \\
\hline & Control & 10.10 & 10.40 & 48.90 & 50.3 & 3.89 & 523 & 5.88 & 6.58 & 8.77 & 9.44 \\
\hline & 30 & & & & & & & 7.58 & 8.11 & 11.96 & 12.32 \\
\hline & 60 & 12.4 & 30 & 55.44 & 59.53 & 688.01 & 732.22 & 8.17 & \begin{tabular}{|l|}
8.27 \\
\end{tabular} & 12.58 & 12.93 \\
\hline & 90 & & & 58.2 & & & & 8.22 & 8.95 & 12.89 & 13.18 \\
\hline \multirow{4}{*}{150} & Con & & & 56.0 & & 588 & 56 & 6.80 & 7.05 & 10.25 & 10.60 \\
\hline & 30 & 12.5 & 12.33 & 57.61 & 57.62 & 722.43 & 710.45 & 8.09 & \begin{tabular}{|l|}
8.21 \\
\end{tabular} & 12.54 & 12.92 \\
\hline & 60 & 13 & & 58.6 & 58. & 7694 & 769.69 & 8.54 & 9.16 & 13.54 & 13.85 \\
\hline & 90 & 14.5 & 14.81 & 60.64 & 61.25 & 880.49 & 907.11 & 10.23 & 10.46 & 15.71 & 15.93 \\
\hline \multirow{4}{*}{300} & Con & 12.19 & 12.12 & 57.45 & 56.90 & 700.31 & 689.63 & 8.05 & 8.21 & 12.32 & 12.53 \\
\hline & 30 & 13 & & 589 & & & 828.93 & 9.04 & 9.35 & 14.19 & 14.70 \\
\hline & 60 & 14.12 & 13.80 & 59.11 & 61.53 & 834.63 & 849.11 & 10.04 & 10.22 & 15.12 & 15.44 \\
\hline & 90 & 16.20 & 15.91 & 64.80 & 64.51 & $104 \mathrm{~s}$ & 1026.35 & 12.71 & 12.27 & 18.64 & 18.3 \\
\hline \multicolumn{2}{|c|}{ L.S.D. at (5\%) } & N.S & N.S & 1.97 & 1.88 & 20.93 & 15.93 & 0.21 & 0.46 & 0.78 & 0.92 \\
\hline
\end{tabular}


Concerning the total yield, it is clear that plants fertilized with the highest sulphur level plus the highest phosphorus level gave the highest yield which were (18.64 and 18.32 tons/fed) in the first and second seasons, respectively. The control plants gave the lowest total yield (8.77 and 9.44 tons/fed), in the first and second seasons, respectively. This increase in yield of pepper as a result of the combined effects of $S$ and $P$ reflects the synergistic role of both elements on the yield and quality (Gopal et al., 2003) on tomato. Those results were confirmed by Niranjana and Devi (1990) and Olsen et al. (1993), on pepper.

Candilo et al. (1994) stated that combining $S$ at $450 \mathrm{~kg} / \mathrm{ha}$ with $P$ at 250 $\mathrm{kg} \mathrm{P}_{2} \mathrm{O}_{5} / \mathrm{ha}$ increased the marketable yield of tomato over the control or those of each element alone. Similar results also were obtained by Mazrouh (2000) on tomato, and Jaggi et al. (2003) on chili pepper. Sarker et al. (2003) conclude that along with increasing $P$ and $S$ levels, number and weight of fruits and total yield of pepper plant markedly increased.

\section{The effect on fruit physical characteristics:}

\section{Effect of sulphur:}

Data in Table (4) show that fruit length and fruit diameter were significantly increased over the control and among the treatments as a result of increasing sulphur application levels. This was clear in the two seasons.

Data in Table (4) also indicate that sulphur application levels resulted in insignificant increase in fruit shape index and flesh thickness in both seasons of study.

The dry matter percentage significantly increased with the increase in sulphur application levels. The increases were associated with each increase in sulphur level. This was evident in the two seasons. The important role of sulphur in photosynthesis and protein synthesis which reflected on the fruit parameters and the dry matter percentage was confirmed $b$ Arora and Lunchra, 1970). Those results are in harmony with those of Shaheen and Omar (1989), Shaheen et al. (1989b) on sweet pepper, Topcuoglu and Yalcin (1997) on tomato, Youssef (2002) on pea plants and Gopal et al. (2003) on tomato.

\section{Effect of phosphorus:}

Results of Table (4) reveal that fruit length and fruit diameter were increased significantly with the increase in phosphorus levels. This was evident throughout the two seasons. Concerning the fruit shape index and flesh thickness, data indicated that they were not significantly affected by the application of phosphorus at the various levels during the two seasons. Dry matter percentage (Table 4) was increased with the increase in phosphorus level. The increments were significant in the two seasons. These results declared the role of phosphorus in the activation of photosynthesis and metabolic processes of organic compounds and hence increasing plant growth and this in turn reflect the positive effect on fruits and yield (Gardener et al., 1985 and Marschner, 1995). These results are coincide with those of Maya et al. (1997), Davies et al. (1999), Murugan et al. (2002), Yusdar and Hanafi (2002), Kaya et al. (2003), Muthumanickam (2003) who concluded that fruit physical characteristics of pepper plants were improved with increasing $P$ levels. 
Sarg, Sawsan, M.H. et al.

Table(4). Effect of each of sulphur and phosphorus on fruit physical characteristic of sweet pepper during 2002 (S1) and 2003 (S2) seasons.

\begin{tabular}{|c|c|c|c|c|c|c|c|c|c|c|}
\hline \multirow{2}{*}{\begin{tabular}{|l} 
Characters \\
Season \\
\end{tabular}} & \multicolumn{2}{|c|}{$\begin{array}{l}\text { Fruit length } \\
(\mathrm{cm})\end{array}$} & \multicolumn{2}{|c|}{$\begin{array}{c}\text { Fruit } \\
\text { diameter } \\
\text { (cm) }\end{array}$} & \multicolumn{2}{|c|}{$\begin{array}{c}\text { Fruit shape } \\
\text { index }\end{array}$} & \multicolumn{2}{|c|}{$\begin{array}{c}\text { Flesh } \\
\text { thickness } \\
\text { (cm) }\end{array}$} & \multicolumn{2}{|c|}{ Dry matter \% } \\
\hline & S1 & S2 & S1 & S2 & S1 & S2 & S1 & S2 & S1 & S2 \\
\hline \multicolumn{11}{|l|}{\begin{tabular}{|l|} 
Treatments \\
(kg S/fed) \\
\end{tabular}} \\
\hline Control & 9.13 & 9.34 & 7.38 & 7.88 & 1.24 & 1.19 & 0.16 & 0.17 & 5.29 & 5.15 \\
\hline 150 & & & 7.77 & 8.93 & 1.25 & 1. & 0.18 & 0.19 & 5.58 & 5.42 \\
\hline 300 & 10.64 & 11.46 & 8.10 & 9.47 & 1.31 & 1.21 & 0.20 & 0.21 & 6.04 & 5.93 \\
\hline L.S.D. at $5 \%$ & 0.55 & 0.82 & 0.53 & 0.43 & 0.05 & N.S & N.S & N.S & 0.15 & 0.12 \\
\hline \multicolumn{11}{|l|}{$\left(\mathbf{k g ~ P} \mathrm{P}_{5} / \mathrm{fed}\right)$} \\
\hline Control & 8.57 & 9.25 & 7.02 & 7.76 & 1.22 & 1.19 & 0.16 & 0.18 & 5.28 & 5.11 \\
\hline 30 & 9.10 & 10.25 & 7.12 & 8.64 & 1.28 & 1.21 & 0.17 & 0.19 & 5.5 & 5.35 \\
\hline 60 & 10.39 & 10.80 & 8.10 & 9.07 & 1.28 & 1.19 & 0.19 & 0.20 & 5.82 & 5.70 \\
\hline 90 & 11.20 & 11.37 & 8.77 & 9.58 & 1.28 & 1.19 & 0.21 & 0.22 & 5.91 & 5.84 \\
\hline L.S.D. at $5 \%$ & 0.59 & 0.83 & 0.64 & 0.50 & N.S & N.S & N.S & N.S & 0.11 & 0.13 \\
\hline
\end{tabular}

\section{Effects of interaction:}

Data presented in Table (5) illustrate the effects of interaction between sulphur and phosphorus treatments on fruit length, fruit diameter, fruit shape index, flesh thickness and dry matter percentage. The interaction effects of the two nutrients indicated that the longest fruits $(12.0$ and $12.37 \mathrm{~cm})$ in the first and second seasons, respectively, were harvested from the plants received the highest sulphur level $(300 \mathrm{~kg} / \mathrm{fed})$ plus the highest phosphorus level $(90 \mathrm{~kg} / \mathrm{fed})$. The shortest fruits were harvested from control plants. The differences among the various treatments were not significant in the two seasons. Fruit diameter, fruit shape index and flesh thickness followed similar trend to those of fruit length throughout the two seasons.

Data in Table (5) show that dry matter \% was significantly increased with the increase of $S$ and $P$ levels in both seasons. The highest sulphur level plus the highest phosphorus level gave the highest dry matter percentages (6.13 and $6.11 \%)$, in the first and second seasons, respectively. The lowest values $(5.00$ and $4.89 \%)$ were obtained from fruits of control plants. The other treatments gained intermediate values in this regard. These results are partially in agreement with those of Mazrouh (2000) and Gopal et al. (2003) both on tomato. 
Table (5). Effect of interaction of sulphur and phosphorus on yield and its components of sweet pepper plants during 2002 (S1) and 2003 (S2) seasons.

\begin{tabular}{|c|c|c|c|c|c|c|c|c|c|c|c|}
\hline \multirow{2}{*}{\multicolumn{2}{|c|}{\begin{tabular}{|l} 
Characters \\
Season \\
\end{tabular}}} & \multicolumn{2}{|c|}{$\begin{array}{l}\text { Length of } \\
\text { fruit }(\mathrm{cm})\end{array}$} & \multicolumn{2}{|c|}{$\begin{array}{l}\text { Diameter of } \\
\text { fruit }(\mathrm{cm})\end{array}$} & \multicolumn{2}{|c|}{$\begin{array}{c}\text { Fruit } \\
\text { shape } \\
\text { index }\end{array}$} & \multicolumn{2}{|c|}{$\begin{array}{l}\text { Fleshy } \\
\text { thickness } \\
\text { (cm) }\end{array}$} & \multicolumn{2}{|c|}{ Dry matter \% } \\
\hline & & S1 & S2 & S1 & S2 & S1 & S2 & S1 & S2 & S1 & S2 \\
\hline \multirow{2}{*}{\multicolumn{12}{|c|}{\begin{tabular}{|l|} 
Treatments \\
Interactions \\
\end{tabular}}} \\
\hline & \multicolumn{11}{|c|}{\begin{tabular}{lll}
\multicolumn{2}{|l|}{ Interactions } \\
$\mathbf{S}$ & levels & levels
\end{tabular}} \\
\hline \multicolumn{12}{|c|}{\begin{tabular}{|l|l} 
& $(k g$ \\
$\mathrm{S} / \mathrm{fed})$ & $(\mathrm{kg}$ \\
$\left.\mathrm{P}_{2} \mathrm{O}_{5} / \mathrm{fed}\right)$ \\
\end{tabular}} \\
\hline \multirow{4}{*}{ Control } & Control & 7.81 & 8.20 & 6.84 & 6.90 & 1.14 & 1.19 & 0.14 & 0.16 & 5.00 & 4.89 \\
\hline & 30 & 8.20 & 9.18 & 6.90 & 7.80 & 1.19 & 1.18 & 0.15 & 0.17 & 5.11 & 4.95 \\
\hline & 60 & 10.00 & 9.90 & 7.40 & 8.20 & 1.35 & 1.21 & 0.17 & 0.18 & 5.43 & 5.28 \\
\hline & 90 & 10.50 & 10.10 & 8.40 & 8.63 & 1.25 & 1.17 & 0.18 & 0.19 & 5.61 & 5.49 \\
\hline \multirow{4}{*}{150} & Control & 8.70 & 9.55 & 7.00 & 8.00 & 1.24 & 1.19 & 0.16 & 0.18 & 5.12 & 4.93 \\
\hline & 30 & 9.00 & 10.28 & 7.15 & 8.51 & 1.26 & 1.21 & 0.17 & 0.19 & 5.39 & 5.20 \\
\hline & 60 & 9.92 & 10.90 & 8.00 & 9.21 & 1.24 & 1.18 & 10.19 & 0.20 & 5.81 & 5.63 \\
\hline & 90 & 11.10 & 11.66 & 8.92 & 10.00 & 1.24 & 1.17 & 0.21 & 0.22 & 6.00 & 5.93 \\
\hline \multirow{4}{*}{300} & Control & 9.20 & 10.00 & 7.21 & 8.39 & 1.28 & 1.19 & 0.17 & 0.19 & 5.73 & 5.51 \\
\hline & 30 & 10.11 & 11.80 & 7.31 & 9.60 & 1.38 & 1.23 & 0.19 & 0.20 & 6.10 & 5.90 \\
\hline & 60 & 11.25 & 11.60 & 8.90 & 9.80 & 1.26 & 1.18 & 0.20 & 0.22 & 6.21 & 6.19 \\
\hline & 90 & 12.00 & 12.37 & 9.00 & 10.11 & 1.33 & 1.22 & 0.23 & 0.25 & 6.13 & 6.11 \\
\hline \multicolumn{2}{|c|}{ L.S.D. at 5\% } & N.S. & N.S & N.S & N.S & N.S & N.S & N.S & N.S & 0.19 & 0.22 \\
\hline
\end{tabular}

\section{The effect on fruit chemical properties:}

\section{Effect of sulphur:}

Data presented in Table (6) indicate that fruit contents of carotenoids, total soluble solids and Vit $\mathrm{C}$ were significantly increased more than controls, as a result of sulphur application. There was a positive relationship between the increase in sulphur levels and the increase in fruit contents of carotenoids, TSS and Vit. C. This was observed in both seasons. Similar results were obtained by Hewedy (1999) on tomato and El-Morsy (2005) on Garlic.

Results of Table (6) also reveal that total acidity was significantly increased as a result of sulphur fertilization, in the two seasons, but the differences between the two sulphur levels were not significant. The increase in carotenoids, T.S.S., Vit. C and total acidity indicated that nutritional values of fruits of sulphur treated plants, were more than those of untreated ones. El-Fayoumy and El-Gamal (1998) on potato came to similar conclusion.

\section{Effect of phosphorus:}

Data in Table (6) declare that fruit contents of the carotneoids were significantly increased with each increase in the level of phosphorus starting from zero, 30, 60 and up to $90 \mathrm{~kg} / \mathrm{fed}$. The differences between all treatments were significant, in the two seasons of study. Data also indicated that total soluble solids were increased with increasing phosphorus levels. It is noticed that the differences between treatments were not significant, except those between each of the control and $30 \mathrm{~kg} / \mathrm{fed}$., or $90 \mathrm{~kg} / \mathrm{fed}$ in the first season. In the second season no significant differences were observed between the 
control and $30 \mathrm{~kg} / \mathrm{fed}$ but the significance was clear between the lowest level of $P(30 \mathrm{~kg} / \mathrm{fed})$ and the highest level $(90 \mathrm{~kg} / \mathrm{fed})$.

Data in Table (6) also show that Vit. C contents were increased with increasing phosphorus levels and the differences between all treatments were highly significant, in both seasons. On the other hand, total acidity was significantly increased with increasing phosphorus level from zero up to 60 $\mathrm{kg} / \mathrm{fed}$ then it decreased with the highest level $(90 \mathrm{~kg} / \mathrm{fed})$. The promoting effect of phosphorus level on Vit. C and T.S.S. were confirmed by Uddin and Begum (1990) on Chili pepper, Koceveski et al. (1995), Murugan (2001) on pepper and El-Morsy et al. (2002) on potato.

\section{Effects of interaction:}

Data presented in Table (6) declare that the highest carotenoids contents $\left(3.27\right.$ and $\left.3.09 \mathrm{mg} / \mathrm{dm}^{2}\right)$ were obtained from the fruits of plants fertilized with the highest level of sulphur $(300 \mathrm{~kg} / \mathrm{fed})$ and the highest level of phosphorus $(90 \mathrm{~kg} / \mathrm{fed})$, in the first and second seasons, respectively. The lowest values (1.95 and $\left.1.79 \mathrm{mg} / \mathrm{dm}^{2}\right)$ were observed in the fruits of control plants. The other different treatments showed intermediate values.

Table (6): Effect of sulphur, phosphorus and their interactions on fruits characteristics of sweet pepper plants, during 2002 (S1) and 2003 (S2) seasons

\begin{tabular}{|c|c|c|c|c|c|c|c|c|c|}
\hline \multirow{2}{*}{\multicolumn{2}{|c|}{\begin{tabular}{|l} 
Characters \\
Season
\end{tabular}}} & \multicolumn{2}{|c|}{$\begin{array}{c}\text { Carotenoids } \\
\left(\mathrm{mg} / \mathrm{dm}^{2}\right)\end{array}$} & \multicolumn{2}{|c|}{ TSS\% } & \multicolumn{2}{|c|}{$\begin{array}{l}\text { Vit. C\% (mg/ } \\
100 \text { g F.W.) }\end{array}$} & \multicolumn{2}{|c|}{ Total acidity $\%$} \\
\hline & & S1 & S2 & S1 & S2 & S1 & S2 & S1 & S2 \\
\hline \multicolumn{10}{|c|}{ Treatments } \\
\hline \multicolumn{10}{|c|}{$\mathbf{S}$ (kg S/fed) } \\
\hline \multicolumn{2}{|l|}{ Control } & 2.47 & 2.30 & 2.31 & 2.53 & 56 & 69 & 0.267 & 0.277 \\
\hline \multicolumn{2}{|l|}{150} & 2.83 & 2.74 & 2.73 & 2.91 & 73 & 94 & 0.301 & 0.315 \\
\hline \multicolumn{2}{|l|}{300} & 2.93 & 2.90 & 2.94 & 3.09 & 94 & 101 & 0.311 & 0.323 \\
\hline \multicolumn{2}{|c|}{ L.S.D. at $5 \%$} & 0.05 & 0.08 & 0.12 & 0.17 & 5.17 & 6.58 & 0.019 & 0.015 \\
\hline \multicolumn{10}{|c|}{$\mathrm{P}\left(\mathrm{kg} \mathrm{P}_{2} \mathrm{O}_{5} /\right.$ fed $)$} \\
\hline \multicolumn{2}{|c|}{ Control } & 2.18 & 2.28 & 2.51 & 2.69 & 55 & 64 & 0.265 & 0.278 \\
\hline \multicolumn{2}{|l|}{30} & 2.76 & 2.55 & 2.60 & 2.77 & 66 & 78 & 0.282 & 0.300 \\
\hline \multicolumn{2}{|l|}{60} & 2.95 & 2.79 & 2.71 & 2.91 & 82 & 92 & 0.316 & 0.327 \\
\hline \multicolumn{2}{|l|}{90} & 3.10 & 2.98 & 2.82 & 3.01 & 94 & 119 & 0.308 & 0.316 \\
\hline \multicolumn{2}{|c|}{ L.S.D. at $5 \%$} & 0.07 & 0.08 & 0.21 & 0.16 & 4.12 & 5.03 & 0.014 & 0.012 \\
\hline \multicolumn{10}{|c|}{ Interactions } \\
\hline \multirow[t]{4}{*}{$\begin{array}{l}\text { S levels } \\
\text { (kg S/fed) }\end{array}$} & \multicolumn{9}{|l|}{$\begin{array}{l}\text { P levels } \\
\left(\mathrm{kgP}_{2} \mathrm{O}_{5}\right. \\
/ \mathrm{fed})\end{array}$} \\
\hline & 30 & 2.35 & 2.19 & 2.29 & 2.53 & 43 & 60 & \begin{tabular}{|l|}
0.239 \\
\end{tabular} & 0.258 \\
\hline & 60 & 2.71 & 2.45 & 2.34 & 2.59 & 68 & 76 & 0.292 & 0.281 \\
\hline & 90 & 2.89 & 2.79 & 2.41 & 2.61 & 80 & 98 & 0.312 & 0.325 \\
\hline \multirow{4}{*}{150} & Control & 2.19 & 2.36 & 2.53 & 2.73 & 52 & 71 & 0.279 & 0.291 \\
\hline & 30 & 2.97 & 2.64 & 2.68 & 2.79 & 65 & 89 & 0.295 & 0.311 \\
\hline & 60 & 3.03 & 2.93 & 2.79 & 3.00 & 82 & 95 & 0.320 & 0.345 \\
\hline & 90 & 3.13 & 3.05 & 2.91 & 3.11 & 96 & 123 & 0.310 & 0.313 \\
\hline \multirow{4}{*}{300} & Control & 2.39 & 2.70 & 2.78 & 2.93 & 81 & 79 & 0.292 & 0.300 \\
\hline & 30 & 2.95 & 2.81 & 2.83 & 2.99 & 90 & 85 & 0.313 & 0.330 \\
\hline & 60 & 3.11 & 3.00 & 3.00 & 3.14 & 97 & 105 & 0.335 & 0.345 \\
\hline & 90 & 3.27 & 3.09 & 3.15 & 3.31 & 108 & 138 & 0.303 & 0.310 \\
\hline \multicolumn{2}{|c|}{ L.S.D. at $5 \%$} & 0.12 & 0.13 & N.S & N.S & 7.13 & 8.71 & 0.024 & 0.021 \\
\hline
\end{tabular}


The interaction effects of sulphur and phosphorus on the T.S.S. showed no significant differences among various treatments, however, the highest values in this concern (3.15 and 3.31\%) were observed in fruits of plants fertilized with $S$ at $300 \mathrm{~kg} / \mathrm{fed}$ plus $P$ at $90 \mathrm{~kg} / \mathrm{fed}$. The lowest T.S.S. values (2.21 and $2.41 \%$ ) were noticed with the control fruits, in the first and second seasons. The differences among the other interactions were not significant in the two seasons. Data in Table (6) also reveal that Vit. C followed similar trend to those of carotenoids and the interaction effects were significant in the two seasons.

Regarding the $S * P$ interaction effects on total acidity data of the same table indicated that the lowest total acidity values $(0.225$ and $0.243 \%)$ were observed in the control fruits in the first and second seasons, respectively. On the other hand, the highest total acidity values $(0.335$ and $0.345 \%)$ was observed in fruits of plants received $S$ at $300 \mathrm{~kg} / \mathrm{fed}$ plus $P$ at $60 \mathrm{~kg} / \mathrm{fed}$, in the first and second seasons, respectively. The differences among the other treatments were significant in the two seasons of study. These results are partially in agreement with those of Niranjana and Devi (1990) on pepper, Candilo et al. (1994), Mahmoud and Amara (2000) and Mazrouh (2000) on tomato.

\section{The effect on fruits mineral contents: \\ Macro-elements content in fruits: \\ Effect of sulphur:}

Results in Table (7) declared that nitrogen, phosphorus, potassium and sulphur contents were increased significantly in fruits of plants received sulphur fertilization levels, compared with controls. The increments among the different treatments were significant in both seasons of study. The results are in agreement with the findings of Topcuoglu and Yalcin (1997) who reported that elemental sulphur application to the soil increased $S, N, P$ and $\mathrm{K}$ in tomato fruits. El-Fayoumy and El-Gamal (1998) stated that applying $S$ to the soil increased phosphorus concentration and uptake by potato tubers. Recently, El-Morsy (2005) confirmed that, N, P and K were significantly increased in garlic cloves with increasing sulphur application level.

\section{Effect of phosphorus:}

Data presented in Table (7) show that each of nitrogen, phosphorus and potassium contents were significantly increased in fruits of treated plants compared with the untreated ones. The increase in fruit contents of the three elements were associated with each increase in $\mathrm{P}$ level from zero and up to $90 \mathrm{~kg} \mathrm{P}_{2} \mathrm{O}_{5} / \mathrm{fed}$. This was evident in the two seasons of study.

Sulphur content increased was significantly with the increase in phosphorus level, compared with control. The differences among various concentrations in both seasons were significant, except those between the medium level $\left(60 \mathrm{~kg} \mathrm{P}_{2} \mathrm{O}_{5} / \mathrm{fed}\right)$ and the highest levels $\left(90 \mathrm{~kg} \mathrm{P}_{2} \mathrm{O}_{5} / \mathrm{fed}\right)$, in the first season. Murugan et al. (2002) and Alabi (2006) reported that increasing phosphorus levels improved $\mathrm{P}, \mathrm{K}$ and $\mathrm{Mg}$ contents of pepper fruits.

\section{Effects of interaction:}

Data in Table (7) show the interaction effects of sulphur and phosphorus on fruit contents of nitrogen, phosphorus, potassium and 
sulphur. Data show that fruits from the untreated plants had the lowest values of nitrogen percentage ( 0.82 and $0.97 \%)$, while the highest level of sulphur plus the highest level of phosphorus gave the highest values (1.64 and $1.61 \%$ ), in the first and second seasons, respectively. The other treatments gained intermediate values, in both seasons of study.

Such data indicated that the highest fruit contents of phosphorus ,potassium and sulphur were obtained from plants fertilized with the highest level of both sulphur and phosphorus in the first and second seasons, respectively. On the other hand, the control fruits showed the lowest values in the first and second seasons, respectively. The other different treatment gained intermediate values. The interaction effects among other treatments were significant in the two seasons.

Table (7): Effect of sulphur, phosphorus and their interactions on fruit macronutrient contents of sweet pepper fruits, during 2002 (S1) and 2003 (S2) seasons.

\begin{tabular}{|c|c|c|c|c|c|c|c|c|c|}
\hline \multirow{2}{*}{\multicolumn{2}{|c|}{\begin{tabular}{|l|} 
Characters \\
Season
\end{tabular}}} & \multicolumn{2}{|c|}{$\mathbf{N} \%$} & \multicolumn{2}{|c|}{ P\% } & \multicolumn{2}{|c|}{$\mathrm{K} \%$} & \multicolumn{2}{|c|}{$\mathbf{S} \%$} \\
\hline & & S1 & S2 & S1 & S2 & S1 & S2 & S1 & S2 \\
\hline \multicolumn{10}{|c|}{ Treatments } \\
\hline \multicolumn{10}{|c|}{ S (kg S/fed) } \\
\hline \multicolumn{2}{|l|}{ Control } & 1.08 & 1.17 & 0.160 & 0.162 & 1.66 & 1.50 & 0.07 & 0.09 \\
\hline \multicolumn{2}{|l|}{150} & 1.34 & 1.35 & 0.181 & 0.196 & 1.98 & 1.76 & 0.11 & 0.13 \\
\hline \multicolumn{2}{|l|}{300} & 1.43 & 1.41 & 0.210 & 0.222 & 2.08 & 1.87 & 0.14 & 0.15 \\
\hline \multicolumn{2}{|c|}{ L.S.D. (5\%) } & 0.07 & 0.04 & 0.008 & 0.009 & 0.06 & 0.03 & 0.01 & 0.02 \\
\hline \multicolumn{10}{|c|}{$\mathrm{P}\left(\mathrm{kg} \mathrm{P}_{2} \mathrm{O}_{5} /\right.$ fed $)$} \\
\hline \multicolumn{2}{|c|}{ Control } & 0.95 & 1.06 & 0.150 & 0.157 & 1.46 & 1.33 & 0.07 & 0.09 \\
\hline \multicolumn{2}{|c|}{30} & 1.24 & 1.25 & 0.171 & 0.178 & 1.79 & 1.56 & 0.10 & 0.11 \\
\hline \multicolumn{2}{|c|}{60} & 1.40 & 1.42 & 0.198 & 0.208 & 2.03 & 1.86 & 0.12 & 0.14 \\
\hline \multicolumn{2}{|c|}{90} & 1.54 & 1.53 & 0.216 & 0.229 & 2.35 & 2.09 & 0.13 & 0.16 \\
\hline \multicolumn{2}{|c|}{ L.S.D (5\%) } & 0.06 & 0.02 & 0.005 & 0.006 & 0.05 & 0.04 & 0.02 & 0.02 \\
\hline \multicolumn{10}{|c|}{ Interactions } \\
\hline \multicolumn{10}{|c|}{\begin{tabular}{|l|l|}
$\begin{array}{l}\text { S levels } \\
\text { (kg S/fed) }\end{array}$ & $\begin{array}{l}P \text { levels } \\
\left(\mathrm{kgP}_{2} \mathrm{O}_{5}\right. \\
\text { (fed) }\end{array}$ \\
\end{tabular}} \\
\hline \multirow{4}{*}{ Control } & Control & 0.82 & 0.97 & 0.126 & 0.115 & 1.26 & 1.18 & 0.04 & 0.06 \\
\hline & 30 & 1.01 & 1.08 & 0.145 & 0.138 & 1.61 & 1.31 & 0.06 & 0.08 \\
\hline & 60 & 1.10 & 1.22 & 0.175 & 0.179 & 1.79 & 1.65 & 0.08 & 0.10 \\
\hline & 90 & 1.39 & 1.42 & 0.193 & 0.215 & 2.00 & 1.84 & 0.09 & 0.12 \\
\hline \multirow{4}{*}{150} & Control & 0.96 & 1.10 & 0.148 & 0.163 & 1.52 & 1.38 & 0.07 & 0.10 \\
\hline & 30 & 1.30 & 1.28 & 0.176 & 0.184 & 1.83 & 1.61 & 0.10 & 0.11 \\
\hline & 60 & 1.51 & 1.49 & 0.193 & 0.208 & 2.10 & 1.93 & 0.13 & 0.15 \\
\hline & 90 & 1.59 & 1.55 & 0.208 & 0.229 & 2.47 & 2.13 & 0.15 & 0.17 \\
\hline \multirow{4}{*}{300} & Control & 1.06 & 1.11 & 0.177 & 0.194 & 1.61 & 1.43 & 0.11 & 0.14 \\
\hline & 30 & 1.42 & 1.39 & 0.191 & 0.213 & 1.94 & 1.75 & 0.13 & 0.15 \\
\hline & 60 & 1.60 & 1.55 & 0.225 & 0.238 & 2.19 & 2.00 & 0.15 & 0.17 \\
\hline & 90 & 1.64 & 1.61 & 0.247 & 0.243 & 2.58 & 2.29 & 0.16 & 0.19 \\
\hline \multicolumn{2}{|c|}{ L.S.D. (5\%) } & 0.10 & 0.04 & 0.009 & 0.100 & 0.10 & 0.08 & N.S & N.S \\
\hline
\end{tabular}

Singh et al. (1995) found that $S$ and other nutrients tended to increase with balanced $P \& S$ fertilizers and application of $S$ and $P$ to the soil led to increase the availability of both elements on potato plants. Gopal et al. (2003) found that the presence of minimum concentration of $P$ facilitates the availability and translocation of sulphur in tomato. They suggested that both 
the nutrients are mobile and with maturity, the translocation is fast and smooth to top parts of plants and accumulated in the fruits of tomato. Also, Kuchawar et al. (2005) reported that the highest content of N, P, K, S in fruits were gained from the highest rates of both elements i.e.90 $\mathrm{kg} \mathrm{P}_{2} \mathrm{O}_{5} / f e d$ and $60 \mathrm{~kg} \mathrm{~S} / \mathrm{fed}$.

\section{Micro-element content in fruits: \\ Effect of sulphur:}

Data in Table (8) show the effect of sulphur fertilization on the fruit Fe, $\mathrm{Zn}$ and $\mathrm{Mn}$ contents. Results indicated that fruit contents of Fe significantly increased with the addition of sulphur fertilizers, compared with control. The increases were associated with the increase in applied sulphur in both seasons of study.

Zinc in the fruits were increased with increasing the applied sulphur compared with control in both seasons. The increments were not significant among all treatments, except those between the control and $150 \mathrm{~kg} \mathrm{~S} / \mathrm{fed}$. in the second season and between control and $300 \mathrm{kgP}_{2} \mathrm{O}_{5 /}$ fed in the two seasons.

$\mathrm{Mn}$ content in the fruits showed similar trend to those of $\mathrm{Fe}$ in the two seasons except that the differences between control and the lowest level in the second season were not significant. This increments may be due to the positive effect of sulphur on the availability of micronutrients by forming compounds which reduced soil $\mathrm{pH}$ and this in turn increase their uptake by plants.

The obtained results are in agreement with those of Topcuoglu and Yalcin (1997) who reported that total $\mathrm{Zn}, \mathrm{Mn}$, Fe contents were generally increased in tomato fruit tissues as a result of sulphur application. ElFayoumy and El-Gamal (1998) and Radwan and Tawfik (2004) showed that $S$ application at the level of $0.03 \%$ caused the highest significant increase in $\mathrm{Fe}, \mathrm{Mn}, \mathrm{Zn}$ and $\mathrm{Cu}$ concentration in potato tissues, tubers and leaves.

\section{Effect of phosphorus:}

Data in Table (8) show that fruit content of Fe was increased significantly with the application of tested phosphorus levels, compared with controls. Fe of fruits increased with increasing phosphorus level up to $60 \mathrm{P}_{2} \mathrm{O}_{5} \mathrm{~kg} /$ fed and then decreased significantly with the level of $90 \mathrm{~kg} \mathrm{P}_{2} \mathrm{O}_{5} / f e d$ although remained significantly higher than control fruits. Concerning $\mathrm{Zn}$ and $\mathrm{Mn}$ contents the trend was similar to those of Fe except that the differences among various treatments were not reach the level of significance, also with $90 \mathrm{~kg} \mathrm{P}_{2} \mathrm{O}_{5} / \mathrm{fed}$, the reduction in fruit content was not significant. (Murugan et al., 2002) reported that increasing $P$ level from 30 up to $60 \mathrm{~kg} / \mathrm{ha}$ improved some micronutrient content of pepper fruit. Alabi, 2006 also found that increasing $\mathrm{P}$ level from 25 and up to $125 \mathrm{~kg} \mathrm{P}_{2} \mathrm{O}_{5} / \mathrm{fed}$., increased pepper fruit contents of $\mathrm{Zn}, \mathrm{Mn}$ and $\mathrm{Fe}$

\section{Effect of interaction:}

Data presented in Table (8) show the interaction effects of sulphur and phosphorus levels on micronutrients contents in pepper fruits. Results indicated that, interaction of $S$ and $P$ at the highest level of $S(300 \mathrm{~kg} \mathrm{~S} / \mathrm{fed})$ and the medium level of $\mathrm{P}\left(60 \mathrm{~kg} \mathrm{P} \mathrm{P}_{5} / \mathrm{fed}\right.$.) gave the highest fruit contents of 
Sarg, Sawsan, M.H. et al.

Fe. The differences between the other treatments were significant in both seasons Data also declare that the interaction effects of $S$ and $P$ on fruit contents of $\mathrm{Zn}$ and $\mathrm{Mn}$ followed the same trend of $\mathrm{Fe}$ except that the differences among treatments were not significant. The control fruits showed the lowest values of $\mathrm{Fe}, \mathrm{Zn}$ and $\mathrm{Mn}$. This was evident in the two seasons. The combined effect of $S$ and $P$ were confirmed by Fenn et al.(1990) and Olsen et al. (1993).. Also Singh et al. (1995) used 0, 25 or $50 \mathrm{~kg} \mathrm{S/ha} \mathrm{with} 80$ $\mathrm{kg} \mathrm{P}_{2} \mathrm{O}_{5}$ /hato fertilize potato plants. and found that $\mathrm{Mg}, \mathrm{Cu}$ and $\mathrm{Fe}$ contents tended to increase with balanced $\mathrm{P}$ and $\mathrm{S}$ fertilizers.

Table (8). Effect of sulphur, phosphorus and their interactions on micronutrients contents of sweet pepper fruits during 2002(S1) and 2003(S2) seasons.

\begin{tabular}{|c|c|c|c|c|c|c|c|}
\hline \multirow{2}{*}{\multicolumn{2}{|c|}{\begin{tabular}{|l|} 
Characters \\
Season \\
\end{tabular}}} & \multicolumn{2}{|c|}{ Fe (ppm) } & \multicolumn{2}{|c|}{ Zn (ppm) } & \multicolumn{2}{|c|}{ Mn (ppm) } \\
\hline & & S1 & S2 & S1 & S2 & S1 & S2 \\
\hline \multicolumn{8}{|c|}{ Treatments } \\
\hline \multicolumn{8}{|c|}{$\mathrm{S}$ (kg S/fed) } \\
\hline Control & & 64 & 57 & 16 & 13 & 15 & 12 \\
\hline 150 & & 71 & 64 & 18 & 16 & 17 & 14 \\
\hline 300 & & 80 & 74 & 20 & 17 & 19 & 18 \\
\hline L.S.D. & & 2.16 & 1.67 & 2.17 & 2.46 & 1.16 & 3.01 \\
\hline \multicolumn{8}{|c|}{$P\left(\mathrm{~kg} \mathrm{P} \mathrm{O}_{5} / \mathrm{fed}\right)$} \\
\hline Control & & 61 & 52 & 16 & 13 & 16 & 13 \\
\hline 30 & & 70 & 63 & 18 & 15 & 17 & 15 \\
\hline 60 & & 81 & 74 & 20 & 18 & 19 & 17 \\
\hline 90 & & 76 & 71 & 18 & 16 & 17 & 15 \\
\hline L.S.D. & & 3.32 & 2.29 & 2.46 & 2.53 & N.S & N.S \\
\hline \multicolumn{8}{|c|}{ Interactions } \\
\hline \multicolumn{8}{|c|}{\begin{tabular}{|l|l|l}
$\begin{array}{l}\text { S levels } \\
\text { S/fed) }\end{array}$ & $(\mathrm{kg}$ Levels \\
$\left(\mathrm{kgP}_{2} \mathrm{O}_{5} / \mathrm{fed}\right)$
\end{tabular}} \\
\hline \multirow{4}{*}{ Control } & Control & 49 & 44 & 14 & 11 & 14 & 11 \\
\hline & 30 & 60 & 53 & 16 & 13 & 15 & 13 \\
\hline & 60 & 78 & 68 & 18 & 16 & 17 & 15 \\
\hline & 90 & 72 & 65 & 17 & 14 & 15 & 12 \\
\hline \multirow{4}{*}{150} & Control & 61 & 50 & 16 & 13 & 16 & 13 \\
\hline & 30 & 68 & 62 & 19 & 16 & 18 & 14 \\
\hline & 60 & 80 & 73 & 20 & 19 & 19 & 16 \\
\hline & 90 & 76 & 71 & 18 & 16 & 18 & 16 \\
\hline \multirow{4}{*}{300} & Control & 73 & 63 & 19 & 15 & 18 & 17 \\
\hline & 30 & 82 & 75 & 21 & 17 & 19 & 18 \\
\hline & 60 & 85 & 81 & 23 & 19 & 21 & 20 \\
\hline & 90 & 81 & 77 & 20 & 18 & 18 & 19 \\
\hline L.S.D. & & 5.73 & 3.47 & N.S & N.S & N.S & N.S \\
\hline
\end{tabular}

\section{REFERENCES}

Alabi, D.A. 2006. Effects of fertilizer phosphorus and poultry droppings treatments on growth and nutrient components of pepper (Capsicum annuum L.). Afri. J. Biotechnology. 5(8): 671-677.

A.O.A.C. 1970. Official Methods of Analysis of the "Association of Official Agricultural Chemists, $10^{\text {th }}$ Edition". Washington, D.C. 
Arora, S.K. and Y.P. Luchra. 1970. Metabolism of S containing amino acids in Phaseolus aureus Linn. Z. Pflanzenemahr. Bodenk. 126: 151-158.

Black, C.A. 1965. "Methods of soil analysis" Part 1. Physical and Mineralogical properties. A.S.A. Madison, Wisc., USA.

Candilo, M.D., G.P. Silvestri, M.Di-Candilo and B.J. Bieche. 1994. Sulphur, calcium and magnesium in processing tomatoes grown in sub- alkaline or sub-acid soils. Acta- Hort. 376: 207-214.

Davies, F.T.J., S.A.Duray, L. Phavaphuthnon and R.S. Stahl. 1999. Influence of phosphorous on gas exchange and plant of two morphologically distinct types of Capsicum annuum. Photosyn. 36(1-2): 99-106.

El-Fayoumy, M.E. and A.M. El-Gamal. 1998. Effects of sulphur application rates on nutrients availability, uptake and potato quality and yield in calcareous soil. Egypt, J. Soil Sci. 38(1-4): 271-286.

El Ghandour, M.A.H. 1965. The interaction of different levels of some fertilizers on the yield and keeping quality of sweet pepper. M.Sc. Thesis, Faculty of Agriculture, Ain Shams University.

El-Morsy, A.H.A. 2005. Effect of sulphur levels and foliar application of certain micronutrients on garlic (Allium sativum L.) The $6^{\text {th }}$ Arabian Conference for Horticulture, Ismailia, Egypt. March 20 - 22.

El-Morsy, A.H.A., A.E. Abdel-Fattah and Z.S.A. El-Shal. 2002. Effect of phosphate fertilizer and vascular mycorrhizal inoculation on growth, tuber yield and quality of sweet potato. Proc. Minia 1 Conf. for Agric. \& Environ. Sci. Minia, Egypt. March 25-28.

FAO 2001. Yearbook production vol. 50 Statistics Series No. 135. FAO. Rome.

Fenn, L.B., H.L. Mistom, T. Riley and G.L. Horst. 1990. Acidification of calcareous soils improves zinc absorption of crops. J. Amer. Soc. Hort. Sci. (115): 741-744.

Freney, J.R., K. Speneer and M.B. Younes. 1978. The diagnosis of sulphur deficiency in wheat. Aust. J. Agric. Res., 29: 727-738.

Gardener, F.D., R.B. Pearce and R.L. Mitchell. 1985. Physiology of crop plants. The lowa State Univ. Press, Amer. 327.

Gopal, R., P. Sinha, B.K. Dube and C. Chatterjee. 2003. Phosphorus sulphur interaction in tomato (Lycopersicon esculentum L.) metabolism. Ind. J. Hort. 60(3): 244-250.

Hewedy, A.M. 1999. Effect of sulphur application and biofertilizer phosphoren on growth and productivity of tomato. Minufiya J. Agric. Res. 24(3): 10763-10787.

Hilal, M.H. 1990. Sulphur in desert Agro - Systems. Proceedings Middle East Sulphur Symposium 12-16 February, Cairo, Egypt, 19-50.

Jaggi, R.C., V.K. Suri and S.P. Dixit. 2003. Comparative performance of sulphur containing and non-containing phosphorus fertilizers on dry chilli (Capsicum annuum) in acid Alfisol. Ind. J. Agric. Sci. 73(1): 49-50.

Kaya, C., D. Higgs, F. Ince, B.M. Amador, A. Cokir and E. Sakar. 2003. Ameliorative effects of potassium phosphate on salt-stressed pepper and cucumber. J. Plant Nut. 26(4): 807-820. 
Kirck, J.T.O. and A.L. Allan 1965. Dependence of chloroplast pigments synthesis in protein synthesis. Effect of actidione. Biochem. Biophys. Res. Commun. 21: 523-530.

Koceveski, V., V. Trpeski and M. Georgievski. 1995. Effect of different doses of $\mathrm{P}_{2} \mathrm{O}_{5}$ in comparison with $\mathrm{K}_{2} \mathrm{O}$ on the yield and morphological and chemical properties of Kurtovska Kapia peppers. Godisen Zbornik na Zemjodelskiot Fakulte Univerzitet. 40: 107-113.

Kuchawar, O.D., P.B. Tirthakar, S.P. Wagh and N.K. Chopde. 2005. Effect of phosphorus, sulphur and iron on content and uptake of nutrient by tomato in Vertisol. J. Soils and Crops. 15(1): 193-198.

Mahmoud, H.A.F. and M.A.T. Amara. 2000. Response of tomato to biological and mineral fertilizers under calcareous soil conditions. Bulletin of Fac. of Agric. Univ. of Cairo. 51(2): 151-174.

Marschner, H. 1995. "Mineral nutrition of higher plants" $2^{\text {nd }}$ Ed. Academic Press London, New York. 8890.

Maya, P.; S. Natarjan and S. Thamburas. 1997. Effect of spacing, N and P on growth and yield of sweet pepper cv. California Wonder. South Indian Horticulture. 45(1-2): 16-18.

Mazrouh, A.Y. 2000. Response of tomato to phosphorus and sulphur application under the conditions of salt affected soils. J. Agric. Res., Tanta Univ. 26(2): 391-403.

Murugan, M. 2001. Quality of chilli (Capsicum annuum L.) variety Co-3 as influenced by levels and sources of phosphorus and levels of nitrogen. J. Spices and Aromatic Crops. 10(1): 1-5.

Murugan, M., S. Backyiarani, A.J. Kumar and A. Subbiah. 2002. Yield and nutrient content of chilli (Capsicum annuum L.) in response to sources of $P$ and levels of $P$ and N. J. Spi. and Aro. Crops. 11(1): 13-17.

Muthumanickam, D. 2003. Influence of different phosphorus sources and zinc spray on the yield and quality of black pepper (Piper nigrum L.) under acid soils. J. Spices and Aromatic Crops. 12(1): 15-18.

Nigri, F.M., S. Vazquez and I.A. Morales. 1999. Fertilization of pepper (Capsicum annuum L.) with NPK under plastic cover. Hort. Argentina. 16(40-41): 64-67.

Niranjana, K.V. and L.S. Devi. 1990. Influence of $P$ and $S$ on yield and quality of chillies. Current $=$ Research - Univ. of Agric. Sci. Bangalore. 19(6): 93-94.

Olsen, J.K., P.J. Lyons and M.M. Kelly. 1993. Nitrogen uptake and utilization by bell pepper in subtropical Australia. J. Plant Nut. 16(1): 177-193.

Page, A.L. 1982. Methods of soil analysis Part 2. Chemical and microbiological properties ( $2^{\text {nd }}$ ed.). Agron. J. Amer. Soc. Agron., Inc. Publ., Madison, Wis. USA.

Radwan, E.A. and A.A. Tawfik. 2004. Effect of sulphur, manganese and zinc on growth, yield and quality of potato (Solanum tuberosum L.) J. Agric. Sci. Mansoura Univ. 29(3): 1423-1431.

Rajput, J.C. and Y.R. Poruleker. 1998. Capsicum in Handbook of vegetable science and technology (D.K. Salunkhe and S.S. Kadam, eds.), Marcel Dekker, Inc. New York, p. 721. 
Rivera, E. and H. Irgazarry. 1984. Effect of fertilization with phosphorus, sulphur and micronutrients on yields of peppers growing on an alkaline soil. J. Agric. Univ. Puerto - Rico. 68(1): 1-4.

Russell, E.J. 1988. Soil conditions and plant growth. 11 th Ed. Alan Wild. Longman Group UK. Ltd. Great Britain.

Sarker, N., A. Kabir, S. Deeder and I. Zahurul. 2003. Response of chilli to integrated fertilizer management in north-eastern brownhill soils of Bangladesh. J. Biol. Sci. 3(9): 797-801.

Shaheen, A.M., M.O. Bakry and M.M. Abou El Maged. 1989a. Response of growth and yield of broad bean (Vicia faba L.) plants to phosphorus and sulphur application. Egypt. J. Appl. Sci., 4(1): 37-83.

Shaheen, A.M. and N.M. Omar. 1989. The elemental fertilization by sulphur and nitrogen their effects on growth and yield of sweet pepper (Capsicum annuum L.) plants. J. Agric. Sci. Mansoura Univ. 14(3): 1692-1699.

Shaheen, A.M., T.T. El-Labban and N.M. Omar. 1989b. Studies on the growth and yield of sweet pepper (Capsicum annuum L.) plants as affected by sulphur and phosphorus nutrition. African J. Agirc. Sci. 16(1-2): 213.

Singh, J.P., R.S. Marwaha and O.P. Srivastava. 1995. Processing and nutritive qualities of potato tubers as affected by fertilizer nutrients and sulphur application. J. Indian Potato Assoc. 22(1-2): 32-37.

Smatanova, M., R. Richter and J. Hluesk. 2004. Spinach and pepper response to nitrogen and sulphur fertilization Plant Soil and Env. 50 (7): 303-308.

Snedecor, C.W. and W.G. Cochran. 1980. Statistical Methods $7^{\text {th }}$ ed. lowa State Univ. Press, p. 504.

Topcuoglu, B. and S.R. Yalcin. 1997. Effects of elemental sulphur applications to calcareous soil on yield and quality properties and some plant nutrient contents of tomato plant grown under covered conditions. Ziraat-Fakultesi-Dergisi, -Akdeniz-Universitesi. 10(1): 196210.

Uddin, M. and S. Begum. 1990. Effect of fertilizers on vitamin C content of green chilli (Capsicum sp.) Bangladesh J. Sci. and Indust. Res. 25(14): $118-124$.

Youssef, A.M. 2002. Growth and yield of pea (Pisum sativum L.) plants as affected by application of sulphur and NPK mixture. J. Agric. Sci. Mansoura Univ. 27(9): 1099-2002.

Yusdar, H. and M.M. Hanafi. 2002. Use of phosphate rock for perennial and annual crops cultivation in Malaysia: a review. Proceedings of an International Meeting Kuala Lumpur Malaysi 
Sarg, Sawsan, M.H. et al.

تأثير استعمال الكبريت المعدني و التسميد الفوسفاتي علي نمو و محصول و جودة ثمار القلقل الحلو الكير

ب- التأثير علي المحصول و صفات الثمار و المكونات الغذائية للثمار

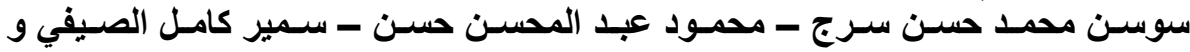

محمد خفاجي رخا

أجريت تجربتان حقليتان فى مزرعة البرامون محطة بحوث البساتين بالمنصورة خلالال الموسم الصيفي

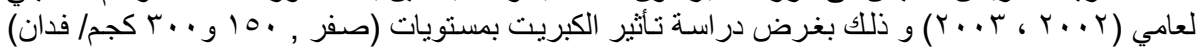

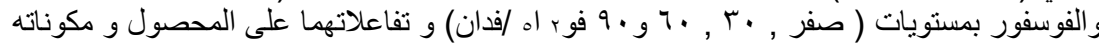

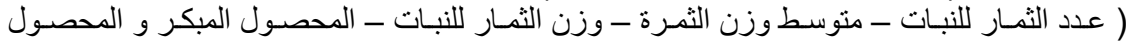

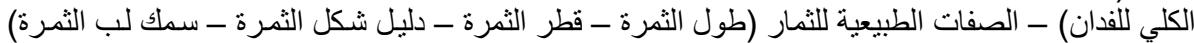

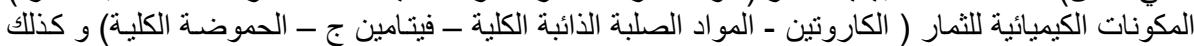

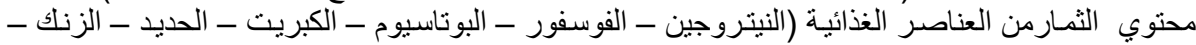

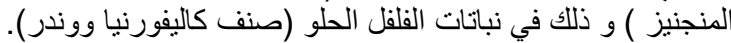

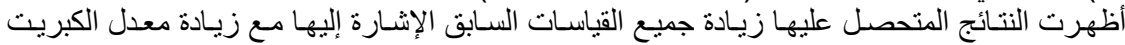

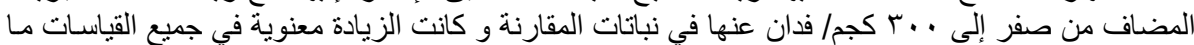

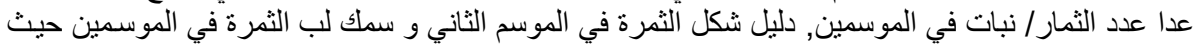
كانت الزيادة بها غير معنوية.

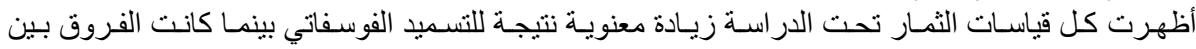

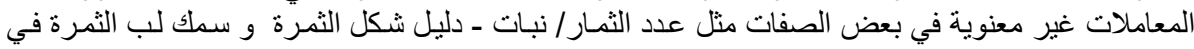

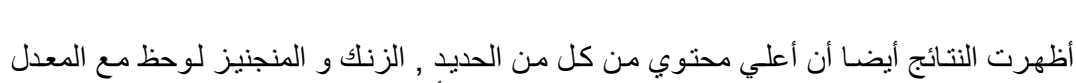

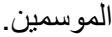

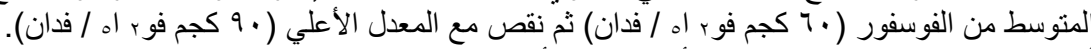

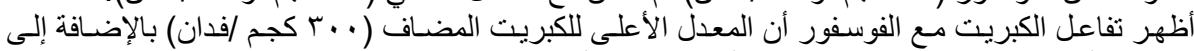

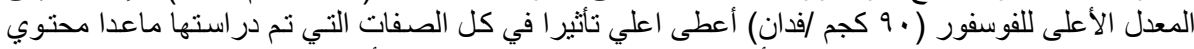

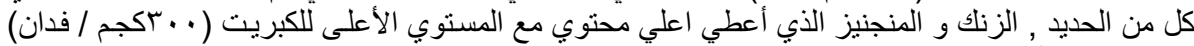
+ المستوي الأوسط للفوسفور ـ كجم فو ب اه / فدان). 